\title{
Earnings Management and Corporate Performance: An Empirical Evidence from Ghana
}

\author{
Zhang Wenfang* Abraham Lincoln Ayisi \\ School of Finance and Economics, Jiangsu University, No. 301 Xuefu Road, Zhenjiang City, Jiangsu \\ Province, China 212013 \\ *E-mail: zhangwf@ujs.edu.cn ablynx04@outlook.com
}

\begin{abstract}
This study aimed at assessing the impact earnings management has on corporate performance of firms on the Ghana Stock Exchange. The study used discretionary accruals of the modified jones model, abnormal cashflow from operations, abnormal discretionary expenses and abnormal production cost to measure earnings management whiles corporate performance was measured using return on assets. The study used a sample of 14 listed companies on the Ghana Stock Exchange (GSE) for the period of 2008 to 2018. We applied multiple linear regression for hypothesis testing. The findings of the study indicate that firm listed on the GSE engages earnings management and manages earnings upwards. Our results indicate earnings management through both accrual earnings and real earnings management techniques have a significant positive effect on corporate performance. Therefore, we recommend an intensive evaluation by the users of financial statements to make competent decisions.
\end{abstract}

Keywords: Accrual Earnings Management, Real Earnings Management, Discretionary Accruals, Corporate Performance

DOI: $10.7176 / \mathrm{RJFA} / 11-10-01$

Publication date:May $31^{\text {st }} 2020$

\section{$1 \quad$ Introduction}

Earnings intuitively called net profit or net income is a single valuable item presented in a firm's income statement. The primary focus is to provide financial information about a firm's performance to stakeholders and for management decision purposes. It serves as a proxy for the measurement of the financial wellbeing of firms so as to ascertain the wealth of stockholders. Firms keep an attractive value to attract the public as indicated by Tabassum, (2015) that prospective investors and corporations are attracted by the positive earnings status of firms that leads to the rise in stock prices. In view of this, managers attempt to yield prospective and influential earnings goals by using strategies and techniques through the provided generally accepted accounting principles (GAAP) to alter reported earnings. This phenomenal attempt or act is referred to as earnings management.

Schipper (1989) defined earnings management as a "purposeful intervention in the external financial reporting process with the intent to obtaining one private gain". Although this definition points out the opportunistic behavior of managers, the likelihood of this drive could be considered to be a win situation for shareholders as well. Earnings management can also be defined as a process used in the Generally Accepted Accounting Principles (GAAP) discipline by managers to manipulate reported figures to misinform users with interest in such figures (Healy and Wahlen, 1999). Managers to an extent diverge from reporting the optimal nature of firms and such engagements detriment the firm's operations leading to future real economic costs. (Ewert \& Wagenhofer, 2005).

In the last decade, many firms in Ghana especially in the banking sector have either been closed down or collapsed and vulnerable investors and customers are the few who suffered the most among other stakeholders. The collapse of such firms was attributed to lack of eligible working capital for operations, however, there was no study or retrospective investigations to affirm the failure was due to any other effect other than the former or the failure was caused by other economic factors or management operations. Such situations bring fears to owners, investors, peer firms and other concerning parties. Respectively, this study is purposely made to make investigations into a possible cause that could affect the corporate performance or destroy the value of firms in Ghana. We therefore look at earnings management and the influential possibilities to firm performance. We believe management uses various methods to manage earnings of firms. Examples of such methods are early recognition of revenue, using estimates to inflate earnings, deliberately delaying earnings and a lot more. These methods impair the transparency, reliability and accuracy of financial reports and can lead to poor decision making (Mintz,2006) and devalue the financial health of firms (Darmawan, T, \& Mardiati, 2019)

This study explores the relationship between earnings management practices and corporate performance measured by Return on Assets (ROA). Earnings management methods in this study is classified into accrual earnings management (AEM) and real earnings management (REM). AEM is applied by making changes to the accounting methods like method of calculating depreciation. REM is also applied by making changes to the structure and time of operations or financial transactions. Unlike developed countries like the US and UK, the practice of earnings management is prevalent in developing countries (Matteo \& Francesco, 2018; Khuong et al. 
2019; Blkasem \& Mansor, 2019); this is due to weak enforcement of laws which makes room for the workaround of underlying financial performance in firms. Considering Ghana as an emerging economy country (Agyekum et al., 2014; Yiadom, 2015), our study is based on the non-financial firms listed on the Ghana Stock Exchange.

Despite the intense practice of earnings management, limited studies have been conducted on the relationship between accrual earnings management (AEM) and real earnings management (REM) and firm performance in Ghana. We find several AEM studies compared to REM and their relationship between performance. We measure earnings management through AEM and REM and how the comprehensive application of these two techniques relate to performance. We also expand the firm year observations of this study which is relatively wider than previous studies (Agyekum et al., 2014; Yiadom, 2015) to deepen and gain a wider overview.

We apply a multiple linear regression in this study using a secondary data gathered from the Ghana Stock Exchange for the period of 2008 to 2018 . We measure AEM with discretionary accruals and measure REM through the manipulation of sales, the reduction of discretionary expenses and overproduction. There are several models for detecting earnings management but this study uses the renowned yet the most efficient modified Jones model (MJM 1991) to detect AEM (Dechow et al., 1995) and considers Roychowdhury (2006) in measuring REM. We consider return on assets (ROA) as the measurement of firm performance and further employ return on equity (ROE) in our robustness test to ensure validity and reliability of results.

This study makes contributions to researchers by increasing the understanding on earnings management and firm performance as well. It contributes to research on the complementary application of AEM and REM. Also, it contributes to research on relationship between ROA and each component of REM measurements. We as well expect this study to be of value to stakeholders, investors and regulators in Ghana particularly to identify and make positive decisions on investments and management as it will facilitate the understanding on how firms manipulate earnings.

The rest of the paper introduces literature and hypothesis development in section 2. Section 3 exhibits population sample, data collection and methodology. In section 4, results and discussions. Our final section presents conclusion, limitations and recommendations.

\section{Literature and Hypothesis Development}

Numerous researches have been conducted to discover the existence of earnings management and the intensity of the practice in factoring the eligibility threshold of firms' value and listing on the stock market. Earnings management is a system for manipulating information and statistics that legally abuse the versatility of GAAP in order to display the content of financial statements in an unreal picture which is contrary to the actual performance of a firm in order to achieve its own management interests (Healy \& Wahlen, 1999; Ding et al., 2018).

The primary purpose of financial statements is to provide quality and useful information to promote and facilitate decisions made by stakeholders. (Mackenzie et al., 2005; Ruiz 2016). Quality reporting of financial statements is strongly recommended to ensure the validity and quality of decisions that rely on the reported earnings. Agency theory draws out the separation of managers acting as agents and the actual owners of the firms (shareholders) provoke the existence of information asymmetry and agency cost. In the absence of shareholders playing a role in the daily activities of the firm, managers prioritize their selfish gains by exploiting their interests at the expense of shareholders. In an attempt to seek their personal interest in accordance with signal theory, managers employ earnings management mechanisms that are not known to shareholders when they are preparing financial statements, nullifying the quality of the report (Healy and Wahlen, 1999). Shareholders may incur cost to restrict the divergence of the managers' interest by providing appropriate measures (Jensen \& Mickling, 1998; Linder \& Foss, 2015).

The existence of earnings management arises in many ways as managers gather the motivation force through the primary goal of meeting thresholds or earnings benchmarks (Li et al., 2011). Outlining the internal causes of earnings management; we find managers to focus on their future compensation or bonus plans as a driven force behind earnings manipulation (Shuto, 2007), the manipulation of results due to weak monitoring mechanisms that could be caused by high level of information asymmetry (Mikhail et al., 1999; Vander \& Willeken, 2000; Arnedo et al., 2007) and lastly capital market motivation as an internal factor that provokes the practice of earnings management as managers attempt to avoid losses, manage earnings upward to meet market expectations. The fundamental intention is to gain advantage over analysts by meeting their forecasts to guarantee the future growth predictions (Myers et al., 1999; Keung et al., 2010; Verma, 2014; Ruiz, 2016).

\subsection{Real Earnings and Accrual Earnings Management}

Earnings management is classified into two methods in this study; Real Earnings Management (REM) and Accrual Earnings Management (AEM). REM is undertaken by making changes to the structure of operation, investment and financial transactions. AEM is applied by changing accounting estimates such as estimates for doubtful debts and changes in the method of depreciation. As managers find it risky to rely on only one of either REM or AEM in order to achieve target earnings, both techniques are considered by normally engaging REM during a fiscal year 
and engage in AEM post fiscal year end (Rochowdhury, 2006).

Due to the passage of Sarbanes-Oxley act of 2002, firms have diverted their earnings approach to REM from AEM. Graham et al. (2005) conducted a study and found out that $80 \%$ of managers manage earnings by applying REM technique instead of AEM. Literature showed evidence that AEM has a significant relationship with REM and both techniques are applied through substitution and complementing methods in different countries (Chou \& Lee, 2018). The application of REM significantly increased in an attempt to meet earnings benchmark as managers tend to reduce the application of AEM (Cohen et al., 2007; Cohen \& Zarowin, 2010; Chan et al., 2015)

Das \& Jena, (2016) examined the relationship between AEM and REM in the Indian context to test whether companies choose substitute relationship over complementary relationship. The results suggested that Indian companies undertake both AEM and REM with a higher predisposition towards AEM. The positive association established supports complementary relationship between the two which indicated that Indian companies use AEM and REM to generate greater benefit from earnings management. Contrary, Khunkaew \& Qingxiang (2019) examined the association between AEM and REM based on 1471 Thai firm observation from 2014-2017 and the results demonstrated a negative relationship between AEM and REM. This implies that Thai firms listed use AEM and REM methods as substitutes.

In times of high REM cost, Chen et al., (2009) added that managers reduce the level of investment in the first period to cut cost of REM in the next period. In the end, earnings will increase when investment is cut in the short run. In that study also, two explanations were made that, future earnings will decrease as managers cut some excessive investment in the first period and secondly, the investment cut down in the first period will possibly increase short-term earnings. Hence, managers exercise interest in reducing AEM to save for the future since they are less concerned about short-term performance.

An empirical investigation into earnings management was made in firms with poor environment performance rating using listed firms in Indonesia from 2002 to 2009 and results show firms report downward earnings to anticipate and avoid political costs and tax (Nurdiniah \& Herlina, 201; Yorke et al., 2016). Verily, the employment of earnings management has received attention with the major concern on the application technique whether the purpose of which earnings are managed is to increase or decrease the report.

Examinations have affirmed the existence and practice of earning managements whether AEM or REM in different firm industries and countries. Researches done on the BRIC-countries and other developing economies indicate the existence of earnings management practices (Shahzad, 2016; Saidu et al. (2017); Matteo and Francesco (2018); Khuong et al. (2019); Blkasem \& Mansor (2019). We therefore expect to detect earnings management practice in firms listed on Ghana Stock Exchange which happens to be one of the developing countries.

H1: Listed firms in Ghana engage in AEM and REM activities.

\subsection{Earnings Management and Firm Performance}

The intensity of earnings management keeps submerging into the affairs of firms so far as their performance and future economic values are concerned. Highlights into the manipulation of income practices by firms to gain market recognition have been made and we find the true performance of firms have been affected by such recognition factor.

Firm performance can be manipulated to present good reports to corporate boards and investors and we find earnings management as the motivator. Managers reluctantly announce earnings that do not meet analysts' forecast since it negatively impacts the performance and possibly the market value (Cohen et al., 2010). In situations like this, managers manipulate the elements of the financial statements specially through the balance sheet and income statement by employing accrual techniques and the practice of real earnings management to maximize the performance of the firms. We commonly find activities such as reducing discretionary spending on R\&D, advertising and maintenance, the lenient credit sales terms and discounted sales to report higher earnings.

Earnings management affects firm performance and tempers with shareholders wealth simply because it involves a deliberate altering of financial information to either misled investors on the real economic position of a firm or to gain some contractual benefits that depend largely on accounting numbers (Watts \& Zimmerman, 1986; Healy \& Wahlen, 1999). Research in this area has put light on possible factors and circumstances that attract managers to practice earnings management to achieve their targets. Studies have discussed the extent of this practice and the performance of firms under different countries and their related different factors. In order to provide the existence of the relationship between earnings management and firm performance, we consider the following empirical evidence.

Commonly, it has been found that when the performance of a firm is low, the adoption of earnings increasing strategies come in to manage earnings upwards, likewise, when there is high performance, the alternate of income decreasing strategies are used to manage earnings downwards. However, Linck et al., 2013 found firms in financial constraint with valuable projects and good investment opportunities adopt discretionary accruals mechanisms to signal positive prospects in order to raise capital for investment. Mostafa (2020) examined whether firms with low performance manage earnings than high performing firms and affirmed in his studies that firms with low 
performance increase their earnings management practices to boost performance as compared to firms with higher performance due to the weakness of shareholder protection and regulatory enforcement in Egypt.

In low performance periods, managers could manage earnings to shield their positions from losses in order to avoid revealing negative performance and this is common in firms with huge accruals (Cornett et al., 2009; Iatridis \& Kadorinis, 2009). Consistently, Lee et al. (2006) used a sample of 67 non-financial firms from 1988 to 2001 to investigate the relationship between earnings management and firm performance. The results show that firms with higher performance increase reported earnings. However, they find a negative association between reported earnings and expected growth.

Tabassum et al., (2015) studied the manufacturing sector of Pakistan from 2004 to 2011 using abnormal operating cash flows, abnormal discretionary expenses and abnormal production cost as proxies for real earnings management. The results came out with a negative earnings management effect on financial performance. Gill et al. (2013) examined the earnings management and firm value of manufacturing firms using Jones accrual model in India and the results showed the practice of earnings management is greater and has a diverse effect on return on assets.

Nuryaman (2013) also studied the post issue IPOs companies' operating performance by exploring the influence of earnings management on stock returns whilst taking into consideration the roles of audit quality as a moderating variable. The sample of the study comprised of 149 manufacturing companies that were listed on the Indonesia Stock Exchange in the year 2010. The total accruals were decomposed to obtain abnormal accruals value using Jones (1991) model. Khuong et al. (2019) analyzed the influence of real earnings management on firm performance of energy listed firms on Vietnam stock exchange and determined that real activity earnings management positively impacts firm performance implying that current sales activities do have a positive impact on current earnings. Firm size, cash from operating activities, return on assets and return on equity as measurement of firm performance all had positive association with earnings management. Mostafa (2020) made a study on firms listed on the Karachi Stock Exchange in Pakistan resulted in a positive significant impact between earnings management and return on assets.

Investigations have shown a negative correlation between accruals and earnings. It was found that, per an increase in earnings, accruals are exercised more to offset cashflows in periods where it will be realized rather than the actual earnings. (Chen et al., 2017; Frankel \& Sun, 2018). In their study, discussions were made that a decrease in cashflows could result in the increase of accruals by managers' discretion when accruals are estimated and reported wrongly to present high earnings to investors.

Given the presence of earnings management and firm performance, existing studies have examined the relationship between them and indicated contradicting evidence of positive relationship (Khuong et al. 2019; Mostafa, 2020) and others, a negative relationship (Tabassum et al., 2013; Gill et al., 2013; Frankel and Sun, 2018). More often than not, the presence of negative relationship comes as a result of strictness and reassessment of reports by investors and regulators using other financial information. On the contrary, previous studies asserted that the practice of earnings management has positively impacted firm performance due to poor regulations and weak perceptions about reported figures. Ghana is a developing country and studies have shown a prevailing practice of earnings management due to weak regulations and scrutinizing of accounting procedures (Khuong et al., 2019). With the view that management manage earnings to show positive performance in firms to mislead investors, the displayed performance could result in positive feedback so as far as the stock market and performance of the firms are concerned. We then develop hypothesis as follows;

H2: AEM positively impacts performance of listed firms on the Ghana stock exchange. H2b: REM positively impacts performance of listed firms on the Ghana stock exchange.

\section{Methodology}

This study adopted descriptive statistics and panel data analysis to examine the trend of earnings management and corporate performance. Specifically, the data gathered were quantitative in nature and further analytical tests of data variables and regression were made. We test for multicollinearity to ascertain the level of intercorrelation to ensure the absence of inaccurate reaction of variables on each other. Our main analysis was tested by applying multiple linear regression to seek the impact of our independent variables on the dependent variable.

\subsection{Sample selection and data collection}

This study focuses on examining the relationship between earnings management (accrual earnings management and real earnings management) and firm performance in non-financial firms listed on the Ghana stock exchange. The first stage of sample selection considered a total number of 43 listed firms. In the second stage, we purposively opted out banks and other financial institutions and omitted firms with incomplete financial reports to ensure data availability within the period of study as well as firms that use currency other than Ghana Cedi as their functional currency. 
Table 1 below shows the sample of 14 firms drawn from the population from the period 2008 to 2018 .

\section{$\underline{\text { Sample Selection Process }}$}

\begin{tabular}{lc} 
Firms listed on the GSE & $\frac{\text { Firms }}{43}$ \\
Less: & \\
Firms not listed on the GSE mainboard & 11 \\
Firms from the financial industry & 14 \\
Firms without complete annual reports from 2008 & 3 \\
Firms with different functional currency & 1 \\
\hline Final sample & 14 \\
\hline
\end{tabular}

The data for the study were collected from the website of Ghana Stock Exchange, independent company official websites and annualreportsghana.com.

\subsection{Variables description}

All variables are summarized and presented in Table 2.

\subsection{Measuring accrual earnings management}

Following Dechow et al. (1995), we measure accruals management using discretionary accruals as a proxy. Accruals include discretionary accruals and non-discretionary accruals. Non-discretionary accruals are restricted by regulations and institutions whereas discretionary accruals can be exploited by managers hence discretionary accruals is reserved as an indicator in the detection of earnings management. Therefore, the mean value of discretionary accruals indicates the level of AEM for all selected firms. Firstly, we estimate discretionary accruals by regressing parameters $\alpha 1, \alpha 2$ and $\alpha 3$ using the Modified Jones model (1995) below;

$$
\frac{T A C C_{i, t}}{T A_{i, t-1}}=\alpha_{1} \frac{1}{T A_{i, t-1}}+\alpha_{2} \frac{\left(\Delta R E V_{i, t}-\Delta R E C_{i, t}\right)}{T A_{i, t-1}}+\alpha_{3} \frac{P P E_{i, t}}{T A_{i, t-1}}+\varepsilon_{t}
$$

All variables are scaled by total assets at year beginning to adjust for heteroscedasticity.

Secondly, we estimate the regression parameters $\hat{\alpha}_{1}, \hat{\alpha}_{2}$ and $\hat{\alpha}_{3}$ to estimate non-discretionary accruals;

$$
\frac{N D A C C_{i, t}}{T A_{i, t-1}}=\widehat{\alpha}_{1} \frac{1}{T A_{i, t-1}}+\widehat{\alpha}_{2} \frac{\left(\Delta R E V_{i, t}-\Delta R E C_{i, t}\right)}{T A_{i, t-1}}+\widehat{\alpha}_{3} \frac{P P E_{i, t}}{T A_{i, t-1}}
$$

The measure of discretionary accruals DACC, is estimated by the difference between TACC and the regressed estimate of NDACC. The absolute value is the indicator of the level of accrual earnings management. Where;

$$
D A C C_{i, t}=\frac{T A C C_{i, t}}{T A_{i, t-1}}-N D A C C_{i, t}
$$

- $\quad T A C C_{i, t}=$ Total accruals in year $\mathrm{t}$ computed as difference between net income and cash flow from operating activities. $T A C C_{i, t}=N E T$ INCOME $-C F O$

- $T A_{t-1}=$ Total assets at the beginning of year $\mathrm{t}$,

- $\Delta R E V_{i, t}=$ Change in revenue in firm $\mathrm{i}$ in year $\mathrm{t}$

- $\triangle R E C_{i, t}=$ Change in receivables in firm i in year $\mathrm{t}$

- $\quad P P E_{i, t}=$ Gross property, plant and equipment in firm $\mathrm{i}$ in year $\mathrm{t}$

- $\quad N D A C C_{i, t}=$ Non-discretionary accruals.

- $\quad D A C C_{i, t}=$ Discretionary accruals

- $\varepsilon_{t}=$ Error term

\subsection{Measuring real earnings management}

Following Roychowdhury (2006); Baatour et al., 2017; Khuong et al., 2019; Darmawan et al., 2019), we apply three basic measures of real earnings management based on abnormal operating cash flows (AB_CFO), abnormal discretionary expenses (AB_DISEXP), and abnormal production cost (AB_PROD). We cross sectionally regress the parameters to estimate the normal levels of cash flows, discretionary expenses and production cost. The residual, which is considered to be the normal level is further subtracted from the actual level to obtain the abnormal levels. Hence, a mean value for the individual basic measures reports the existence for the respective 
measures of REM in all selected firms. The measurement of the various proxies of real earnings management are as follows;

We use the below model to estimate the normal operation cash flow;

$$
\begin{aligned}
& \frac{C F O_{t}}{T A_{t-1}}=\alpha_{0}+\alpha_{1} \frac{1}{T A_{t-1}}+\beta_{1} \frac{s_{t}}{T A_{t-1}}+\beta_{2} \frac{\Delta S_{t}}{T A_{t-1}}+\varepsilon_{t} \\
& \mathrm{AB}_{\mathrm{CFO}}=\frac{C F O}{T A_{t-1}}-N O R M A L_{C F O}
\end{aligned}
$$

We estimate normal discretionary expenses as follows:

$$
\begin{gathered}
\frac{\text { IISEXP }_{t}}{T A_{t-1}}=\alpha_{0}+\alpha_{1} \frac{1}{T A_{t-1}}+\beta \frac{s_{t}}{T A_{t-1}}+\varepsilon_{t} \\
\mathrm{AB}_{\text {DISEXP }}=\frac{\text { DISEXP }_{t}}{T A_{t-1}}-N O R M A L_{\text {DISEXP }}
\end{gathered}
$$

We estimate normal production cost with the model below:

$$
\begin{gathered}
\frac{P R O D_{t}}{T A_{t-1}}=\alpha_{0}+\alpha_{1} \frac{1}{T A_{t-1}}+\beta_{1} \frac{S_{t}}{T A_{t-1}}+\beta_{2} \frac{\Delta S_{t}}{T A_{i, t-1}}+\beta_{3} \frac{\Delta S_{t-1}}{T A_{t-1}}+\varepsilon_{t} \\
\mathrm{AB}_{\mathrm{PROD}}=\frac{P R O D_{t}}{T A_{t-1}}-N O R M A L_{P R O D}
\end{gathered}
$$

Where:

$C F O_{t}=$ Cash flow from operation firm $\mathrm{i}$ in year $\mathrm{t}$.

$P R O D_{t}=$ Production cost of firm i in year t. computed by COGS $+\triangle I N V E N T O R Y$

$\operatorname{DISEXP} P_{t}=$ Discretionary expenses of firm $\mathrm{i}$ in year $\mathrm{t}$.

$\mathrm{AB}_{\mathrm{CFO}}=$ Abnormal cash flow from operation.

$\mathrm{AB}_{\text {DISEXP }}=$ Abnormal discretionary expenses.

$\mathrm{AB}_{\mathrm{PROD}}=$ Abnormal production cost.

$T A_{t-1}=$ Total assets of firm $\mathrm{i}$ in year $\mathrm{t}-1$.

$S_{t}=$ Total sales of firm $\mathrm{i}$ in year $\mathrm{t}$.

$\Delta S_{t}=$ Changes in sales of firm $\mathrm{i}$ in year $\mathrm{t}$.

$\Delta S_{t-1}=$ Changes in firm sales $\mathrm{i}$ in year $\mathrm{t}-1$.

$\varepsilon_{t}=$ Error.

\subsection{Measuring firm performance}

Data used in this study for measuring firm performance were acquired from the annual reported financial statements of firms listed on the Ghana stock exchange.

Following (Ding et al., 2018; Liu, 2018; Petitjean, 2019), Return on assets (ROA) is used as the proxy for firm performance. Return on assets shows how efficient a company uses its assets to generate earnings. ROA is estimated by dividing net income by total assets.

\subsection{Model specification}

We define the variables of the model that measure the earnings management and financial performance. The rationale behind these variables is due to their application in accounting literature to express the quality of firm performance and earnings management results.

To test hypotheses $2 \mathrm{a}$ and $2 \mathrm{~b}$ we construct a regression model to investigate the relationship between earnings management (AEM and REM) on firm performance.

$\mathrm{ROA}=\beta_{0}+\beta_{1} \mathrm{DACC}+\beta_{2} \mathrm{AB}_{\mathrm{CFO}}+\beta_{3} \mathrm{AB}_{\mathrm{DISEXP}}+\beta_{4} \mathrm{AB}_{\mathrm{PROD}}+\beta_{5} \mathrm{SIZE}+\beta_{6} L E V+\beta_{7} L Q D T+\varepsilon$ 
Table 2: Description of Variables

\begin{tabular}{|c|c|c|}
\hline Variable & Symbol & Measurement \\
\hline \multicolumn{3}{|l|}{ Dependent variable } \\
\hline Return on assets & ROA & Net income divided natural log of total assets \\
\hline \multicolumn{3}{|l|}{ Independent variables } \\
\hline Discretionary accruals & DA & Total accruals minus Non-discretionary accruals \\
\hline Abnormal Cash Flow & AB_CFO & $\begin{array}{l}\text { Estimated value of Normal CFO from actual value of } \\
\text { CFO }\end{array}$ \\
\hline Abnormal Discretionary expenses & AB_DISEXP & \\
\hline Abnormal Production Cost & AB_PROD & $\begin{array}{l}\text { Estimated value of normal Discretionary Expenses from } \\
\text { actual value discretionary expenses } \\
\text { Estimated value of normal production cost from actual } \\
\text { value of production cost }\end{array}$ \\
\hline \multicolumn{3}{|l|}{ Control variables } \\
\hline Firm size & SIZE & Natural log of total assets \\
\hline Leverage & LEV & Book value of debt divided by total assets \\
\hline Liquidity & LQDT & Current assets divided by current liability \\
\hline
\end{tabular}

\section{Results and Discussions}

\subsection{Descriptive Statistics}

Table 3 presents a detailed description of the selected variables used in this study. The dependent variable ROA and four other measurements of earnings management as our independent variables. Additionally, we introduce three control variables; firm size, leverage and liquidity. The mean value of ROA is 0.0793 which explains average profitability of the studied firms, a standard deviation of 0.323 and minimum and maximum of -0.520 and 3.722 respectively. The minus sign on ROA minimum value indicates some firm made losses in the period of study analysis. The average value of DA is 0.133 with a standard deviation of 0.177 . Minimum and maximum for DA are 0.00078 and 1.477 respectively. Mean value of AB_CFO, AB_DISEXP and AB_PROD is 0.74, 1.31 and 4.55 respectively. Abnormal Cash flow shows the highest mean of $7.4 \overline{8}$ amongst the proxies for REM indicating firms engages in radical discount sales and lenient sales offers to boost revenue. Similar with AB PROD, the higher mean value for $\mathrm{AB}$ _ DISEXP shows firms on average make huge spending on advertisement, $\mathrm{R} \& \mathrm{D}$ and other general expenses. Firm size denoted by SIZE which is the natural logarithm of firm total assets shows the highest average value amongst the control variables of 7.59 with a standard deviation of 0.78 .

Table 3: Descriptive Statistics

\begin{tabular}{|c|c|c|c|c|}
\hline Variable & Mean & Std. Dev & Minimum & Maximum \\
\hline ROA & 0.0793493 & 0.323954 & -0.5200738 & 3.722273 \\
\hline DA & 0.1332606 & 0.1776485 & 0.0007868 & 1.477352 \\
\hline AB_CFO & 0.7482508 & 0.2217481 & -1.179782 & 1.154691 \\
\hline AB_DISEXP & 1.3156108 & 0.5517862 & -0.756073 & 4.769411 \\
\hline AB_PROD & 4.5594209 & 0.8521605 & -4.190839 & 5.389097 \\
\hline SIZE & 7.59556 & 0.783432 & 5.97936 & 9.041197 \\
\hline LEV & 0.0822872 & 0.1332653 & 0 & 0.7449987 \\
\hline LQDT & 1.981798 & 2.65299 & 0.1615076 & 17.668 \\
\hline
\end{tabular}

\subsection{Listed Firms in Ghana Engage in Real and Accrual Earnings Management}

Supporting (Agyekum et al., 2014; Yiadom, 2015; Shahzad, 2016), we confirm our first hypothesis that earnings management exist in firms listed on the Ghana Stock Exchange as discretionary accruals recorded a positive mean value of 0.133 indicating that, the sample firms engages in AEM to obtain desired profit and avoid reporting losses by increasing earnings.

Similarly, we confirm the presence of REM as AB_CFO, AB_DISEXP and AB_PROD all recorded positive mean values for all selected firms indicating upwards earnings management to obtain desired profit. We can conclude that, having mean values greater than 0 represents the presence of upward earnings management likewise, negative values indicate the practice of downward earnings management per the models used in detecting AEM and REM and thus, the sample firms not only engage in earnings management but also uses the positive earnings 
approach to report upward earnings. Our objective indicates no interest in the direction of earnings management; however, we signal an opposite outcome of results with the findings of (Taylor \& Xu, 2010; Nurdiniah \& Herlina, 2015) asserting the presence of downward earnings management. We find our results consistent with (Roychowdhury, 2006; Chan et al., 2015) that firms employ both the AEM and REM techniques. We support Graham et al., (2005) in the sense that the application of REM is dominant over AEM in recent times and as well support (Saidu et al. 2017; Matteo and Francesco, 2018; Khuong et al., 2019; Blkasem and Mansor, 2019) that earnings management is very common in developing economies concurring with Mostafa, (2020) assertions that, firms under developing economies have more incentives to engage in earnings management activities.

\subsection{Correlation Analysis}

Table 4 reports the adoption of Pearson correlation of the variables in our study to establish a link between earnings management and financial performance of firms. We find all independent variables: DA, AB_CFO, AB_PROD but AB_DISEXP positively correlated with the dependent variable ROA. ROA is also positively related to our control variables, SIZE and LQDT but negatively related to LEV. The maximum correlation coefficient of the independent variables is 0.28 and thus, does not raise concerns about multicollinearity. As suggested by (Ziegel et al., (1996), our outcome is in accordance with the Pearson correlation coefficient which defines the independent variables to be inferior to 0.75 . with respect to VIF, we conform with the rule that, a variable to inferior 5 (VIF $<5$ ) denoting the absence of multicollinearity in the variables.

Table 4: Pearson Correlation Coefficient Matrix

\begin{tabular}{|l|c|c|c|c|c|c|l|l|l|}
\hline & ROA & DA & AB_CFO & AB_DISEXP & AB_PROD & SIZE & LEV & LQDT & VIF \\
\hline ROA & 1.0000 & & & & & & & & \\
\hline DA & $0.2898^{*}$ & 1.000 & & & & & & & 2.94 \\
\hline AB_CFO & $0.2558^{*}$ & $-0.7863^{*}$ & 1.0000 & & & & & & 2.94 \\
\hline AB_DISEXP & -0.0338 & -0.0323 & -0.0297 & 1.0000 & & & & & 1.17 \\
\hline AB_PROD & 0.0716 & -0.1140 & 0.1300 & $-0.3508^{*}$ & 1.0000 & & & & 1.13 \\
\hline SIZE & 0.0945 & -0.0791 & 0.0189 & -0.0029 & -0.0812 & 1.0000 & & & 1.13 \\
\hline LEV & -0.0559 & -0.0886 & -0.0358 & -0.0221 & 0.0203 & $0.2356^{*}$ & 1.0000 & & 1.18 \\
\hline LQDT & 0.0657 & 0.0632 & 0.0594 & 0.0174 & -0.0304 & -0.0389 & -0.1500 & 1.0000 & 1.10 \\
\hline MEAN VIF & & & & & & & & & 1.66 \\
\hline
\end{tabular}

Note: * implies significant at 5\%, VIF (Variance Inflation Factor)

\subsection{Regression analysis}

In attempt to confirm hypotheses 2 and $2 \mathrm{~b}$, we employed multiple linear regression in our regression analysis of which the study sought to examine. Table 5 reports the regression analysis that examines the relationship between earnings management (real and accrual earnings management) and corporate performance. Results unveiled the coefficient of DA to have a positive significance of $(0.80, z=18.26)$. This result shows that a unit increase in DA will lead to a 0.80 increase in firm performance. The coefficient of abnormal cash flow is $(0.76, z=17.55)$. Taking into account the other measurement of real earnings management, we find both AB_DISEXP and AB_PROD to be significantly positive with coefficients of $(0.020, \mathrm{z}=1.92)$ and $(0.018, \mathrm{z}=2.59)$ respectively.

Table 5: Regression results

\begin{tabular}{|l|l|l|l|l|}
\hline Variables & Coefficient & Standard Error & $\mathrm{Z}$ & $\mathrm{P}>|\mathrm{z}|$ \\
\hline DA & 0.8061246 & 0.0441557 & 18.26 & 0.000 \\
\hline AB_CFO & 0.7699556 & 0.0438681 & 17.55 & 0.000 \\
\hline AB_DISEXP & 0.020603 & 0.010743 & 1.92 & 0.058 \\
\hline AB_PROD & 0.0189478 & 0.0073183 & 2.59 & 0.011 \\
\hline SIZE & 0.0548723 & 0.0077298 & 7.10 & 0.000 \\
\hline LEV & -0.127835 & 0.0581211 & -2.20 & 0.030 \\
\hline LQDT & 0.0038954 & 0.003277 & 1.19 & 0.237 \\
\hline CONS & -0.3606948 & 0.0582492 & -6.19 & 0.000 \\
\hline R-squared & 0.7975 & F(7, 118) & 66.38 & \\
\hline Adj R-squared & 0.7855 & Prob $>$ F & 0.0000 & \\
\hline & & Number of obs & 140 & \\
\hline & & Number of grps & 14 & \\
\hline
\end{tabular}

We find control variables; SIZE to be positively significant with $(0.0548, \mathrm{z}=0.000)$, LEV turns out to be negatively significant $(-0.127, \mathrm{z}=0.30)$. By these results, we find that earnings management through sales manipulation, reduction in discretionary expenses and excess production positively impacts firm performance. The 
independent variable depicted a $79.75 \%$ variability in our dependent variable. This shows that with the R-squared of $79.75 \%$, the dependent variable return on assets is highly explained by the independent variables; accrual earnings and real earnings management as well as the control variables firm size, leverage and liquidity.

\subsection{Impact of Earnings Management (AEM and REM) on Firm Performance (ROA)}

On account of Table 5, results correspond to hypothesis 2 and hypothesis $2 b$ of the study which indicates DA is significantly positive as well as the proxies of real earnings management to corporate performance. The finding of DA in this study is similar to Mostafa, (2020), who found that ineffective firms in Egypt are characterized upward accrual earnings practices to stabilize their performances as well the findings of Linck et al., (2013). We find results unsupportive to Younesi \& Hashemijoo, (2012), who examined the relationship between earnings management and performance Malaysians and found a negative relationship following the acquisition date of shares as well as other previous findings (Shirzad et al., 2015; Okafor, 2018). Further, real earnings through cash flows results differently with other studies considering the evident approach of firms in Ghana to accelerate sales by offering discount sales to signal positive corporate earnings. This is consistent with findings of (Gunny, 2010; Kothari et al., 2016; Jiang et al., 2018; Khuong et al., 2019) that firms tend to accelerate profit and performance through accrual and real earnings management approach and contradicts findings of (Tang \& Chang, 2014; Tabassum et al., 2015; Yorke et al., 2016; Tian et al., 2018 Dakhlallh, 2020) indicating negative relationships between proxies of earnings techniques and performance of firms. For the control variables, we found the firm size have a positive significant relationship with return on assets. Unlike leverage with a negative effect, same cannot be said about liquidity with an insignificantly result on return on assets.

We consider our model to be valid and significant enough to jointly predict AEM and REM as suggested by Dakhlallh, (2020). Consistent with agency and signal theories, we found our results to be compatible with our hypothesis that the practice of earnings management positively affects firm performance. The results as well explains earnings management could help management to ease financial constraints by approaching investors and regulators with decent investment offers (Linck et al., 2013)

\subsection{Robustness test}

We conduct a robustness test to confirm the above results. Due to reason of brevity, we present the regression of results only. Results are presented specifically to indicate the replacement of return on assets (ROA) with return on equity (ROE) as the measurement of firm performance as our dependent variable. ROE is calculated as ratio of earnings before tax over total equity. Our independent variables and control variables remain the same. Thus, we repeat the regression test for hypotheses 2 and $2 b$.

Table 6: Regression results of robustness test using ROE

\begin{tabular}{|l|l|l|l|l|}
\hline Variables & Coefficient & Standard Error & $Z$ & $\mathrm{P}>|\mathrm{z}|$ \\
\hline DA & 2.583749 & 0.8437295 & 3.06 & 0.003 \\
\hline AB_CFO & 2.242174 & 0.8577019 & 2.61 & 0.010 \\
\hline AB_DISEXP & 0.0463462 & 0.1819464 & 0.25 & 0.799 \\
\hline AB_PROD & -0.2515993 & 0.3779378 & -0.67 & 0.507 \\
\hline SIZE & 0.4257538 & 0.1543291 & 2.76 & 0.007 \\
\hline LEV & -0.2957911 & 1.115507 & -0.27 & 0.791 \\
\hline LQDT & 0.0031837 & 0.0616999 & 0.05 & 0.959 \\
\hline CONS & -3.283431 & 1.153757 & -2.85 & 0.005 \\
\hline R-squared & 0.1522 & F(7, 118) & 3.03. & \\
\hline Adj R-squared & 0.1019 & Prob $>$ F & 0.0058 & \\
\hline & & Number of obs & 140 & \\
\hline & & Number of grps & 14 & \\
\hline
\end{tabular}

Table 6 presents the results of our robustness test. We find the results similar in terms of the association between earnings management and firm performance considering DA and AB CFO to have a positive relationship. We however find no relationship between $\mathrm{AB}$ DISEXP and AB PROD with firm performance.

\section{Conclusion}

Contributing to literature, our study adds up to earnings management resources. We examined how the performance of firms via Return on asset (ROA) can be influenced by two earnings management techniques; accrual earnings management and real earnings management. The examination was instrumentalized by setting discretionary accruals as a proxy for accrual earnings and three other proxies; abnormal cash flow from operations, abnormal discretionary expenses and abnormal production cost constituting real earnings management. Studies have swiftly advanced in the quest of explaining the relationship between earnings management and firm performance and we affirm that with this study. 
Initial assumptions of multicollinearity and highly correlated of data were present. Hence, series of test were done to clear doubts on the presence of multicollinearity to ensure data is confidently fit to produce valid results.

Our initial examination established the existence of earnings management practices in listed firms on the Ghana Stock Exchange. We consider our results to affirm the need of putting measures and secured regulations to minimize the abnormal level of earnings management practices in developing economies especially in Ghana. Secondly, we assessed the extent to which earnings management affects firm performance. In the period of 2008 to 2018 our regression results came out with positive relationship between our main variables of study which is in line with our stated hypothesis. Based on the analysis, we found that firms listed on the Ghana Stock Exchange to engage in both accrual and real earnings management practices with a positive significant effect on corporate performance.

We count this study as a support and contribution to the limited number of studies that are made on earnings management and firm performance with a sample of Ghana firms by including both AEM and REM techniques in the measurement of earnings management with a wider year observation. We find our study to have contributions for investors, managers, academicians and regulators. It contributes to literature by addressing factors that account and result in the increment of earnings management to subsequent underlying outcome of such practice. We find the outcome to be positively connected with firm performance.

Additionally, we can conclude that though the performance of non-financial firms listed on the Ghana Stock Exchange are positively affected, we strongly advice authorities and facilitators to enforce regulations to present transparent financial information to combat unprecedent mitigation of deceptive performance so as to regulate the level of discretion by managers. Also, in-depth analysis of financial statements must be exercised by prospective investors prior their investments. Positively, our study highlights the acceptance of earnings management by firms with prospective investment opportunities to improve their performance financially. Lastly, our study has contributed to knowledge on earnings management to have a positive implication on firm performance by signaling positive future performance rather than a harmful effect.

\subsection{Limitations}

Our study was on a limited number of sampled firms listed on the Ghana Stock Exchange and findings could not be generalized to other firms in Ghana. Our investigations into accrual earnings management was limited to the modified jones model other than numerous developed models. We also limited examination of firm performance by ROA without taking into account other measures of firm performance. We suggest an expanded dimension with regards to both earnings management and firm performance measurements.

\section{References}

Agyekum, A. A. B., Otchere, F. A., \& Bedi, I. (2014). Earnings management and corporate governance: the Ghanaian experience. International Journal of Management Practice, 7(4), 309. https://doi.org/10.1504/ijmp.2014.065229

Arnedo, L., Lizarraga, F., \& Sánchez, S. (2007). Does public/private status affect the level of earnings management in code-law contexts outside the United States? A study based on the Spanish case. The International Journal of Accounting, 42(3), 305-328. https://doi.org/10.1016/j.intacc.2007.06.004.

Baatour, K., Ben Othman, H., \& Hussainey, K. (2017). The effect of multiple directorships on real and accrualbased earnings management. Accounting Research Journal, 30(4), 395-412. https://doi.org/10.1108/arj-062015-0081

Blkasem, E \& Mansor, N. (2019). Earnings Management in Developed and Developing Countries: A Review of Recent Literature. American Based Research Journal. 8(1) 2304-7151.

Chan, L. H., Chen, K. C. W., Chen, T. Y., \& Yu, Y. (2015). Substitution between Real and Accruals-Based Earnings Management after Voluntary Adoption of Compensation Clawback Provisions. The Accounting Review, 90(1), 147-174. https://doi.org/10.2308/accr-50862

Chen, S., Wang, Y., \& Zhao, Z. (2009). Regulatory Incentives for Earnings Management through Asset Impairment Reversals in China. Journal of Accounting, Auditing \& Finance, 24(4), 589-620. https://doi.org/10.1177/0148558x0902400405

Chou, P.-I., \& Lee, C.-H. (2018). The asymmetric relation between earnings management behaviors: evidence from executive compensation incentives. Journal of Economics and Finance, 42(4), 765-778. https://doi.org/10.1007/s12197-018-9426-1

Cohen, D. A., \& Zarowin, P. (2010). Accrual-based and real earnings management activities around seasoned equity offerings. Journal of Accounting and Economics, 50(1), 2-19. https://doi.org/10.1016/j.jacceco.2010.01.002

Cohen, D. A., Dey, A., \& Lys, T. Z. (2007). Real and Accrual-Based Earnings Management in the Pre- and PostSarbanes Oxley Periods. SSRN Electronic Journal. https://doi.org/10.2139/ssrn.813088

Cornett, M. M., McNutt, J. J., \& Tehranian, H. (2009). Corporate governance and earnings management at large 
U.S. bank holding companies. Journal of Corporate Finance, 15(4), 412-430. https://doi.org/10.1016/j.jcorpfin.2009.04.003

Dakhlallh, M. M. (2020). Accrual-based Earnings Management, Real Earnings Management and Firm Performance: Evidence from Public Shareholders Listed Firms on Jordanian's Stock Market. Journal of Advanced Research in Dynamical and Control Systems, 12(1), 16-27. https://doi.org/10.5373/jardcs/v12i1/20201004

Darmawan, I. P. E., T, S., \& Mardiati, E. (2019). Accrual Earnings Management and Real Earnings Management: Increase or Destroy Firm Value? International Journal of Multicultural and Multireligious Understanding, 6(2), 8. https://doi.org/10.18415/ijmmu.v6i2.551

Das, R. C., \& Jena, S. K. (2016). Earnings Management and Equity Issue Firms: A Study in Indian Context. Jindal Journal of Business Research, 5(1), 64-85. https://doi.org/10.1177/2278682116680926

Dechow, P.M., R.G. Sloan \& A.P. Sweeney. (1995). Detecting Earnings Management, The Accounting Review, 70, 193-225.

Ding, R., Li, J., \& Wu, Z. (2018). Government affiliation, real earnings management, and firm performance: The case of privately held firms. Journal of Business Research, 83, 138-150. https://doi.org/10.1016/j.jbusres.2017.10.011.

Ewert, R., \& Wagenhofer, A. (2005). Economic Effects of Tightening Accounting Standards to Restrict Earnings Management. The Accounting Review, 80(4), 1101-1124. https://doi.org/10.2308/accr.2005.80.4.1101.

Frankel, R. M., \& Sun, Y. (2018). Predicting Accruals Based on Cash-Flow Properties. The Accounting Review, 93(5), 165-186. https://doi.org/10.2308/accr-52001

Gill, Amarjit \& Biger, Nahum \& Mand, Harvinder \& Mathur, Neil. (2013). Earnings Management, Firm Performance, and the Value of Indian Manufacturing Firms. International Research Journal of Accounting and Economics, 116, 1450-2887

Gong, G., Louis, H., \& Sun, A. X. (2008). Earnings Management and Firm Performance Following Open-Market Repurchases. The Journal of Finance, 63(2), 947-986. https://doi.org/10.1111/j.1540-6261.2008.01336.x

Graham, J. R., Harvey, C. R., \& Rajgopal, S. (2005). The Economic Implications of Corporate Financial Reporting. SSRN Electronic Journal. https://doi.org/10.2139/ssrn.491627

Gunny, K. A. (2010). The Relation Between Earnings Management Using Real Activities Manipulation and Future Performance: Evidence from Meeting Earnings Benchmarks*. Contemporary Accounting Research, 27(3), 855-888. https://doi.org/10.1111/j.1911-3846.2010.01029.x

Healy, Paul, and James Wahlen, 1999, A review of the earnings management literature and its implications for standard setting, Accounting Horizons 13, 365-383.

Iatridis, G., \& Kadorinis, G. (2009). Earnings management and firm financial motives: A financial investigation of UK listed firms. International Review of Financial Analysis, 18(4), 164-173. https://doi.org/10.1016/j.irfa.2009.06.001.

Jiang, H., Habib, A., \& Wang, S. (2018). Real Earnings Management, Institutional Environment, and Future Operating Performance: An International Study. The International Journal of Accounting, 53(1), 33-53. https://doi.org/10.1016/j.intacc.2018.02.004.

Jensen, M. C., \& Meckling, W. H. (1998). Theory of the Firm: Managerial Behavior, Agency Costs and Ownership Structure. SSRN Electronic Journal. https://doi.org/10.2139/ssrn.94043ding

Kueng, E., Lin, Z., \& Shih, M. (2010). Does the Stock Market See a Zero or Small Positive Earnings Surprise as a Red Flag? Journal of Accounting Research, 48(1), 105-136. https://doi.org/10.1111/j.1475679x.2009.00354.x

Khunkaew, R., \& Qingxiang, Y. (2019). Substitution between accruals-based and real activities earnings management of listed Thai firms. Journal of Corporate Accounting \& Finance. https://doi.org/10.1002/jcaf.22406

Khuong, N. V., Nguyen, T. H. \& Phung, A. T. (2019). The Relationship between Real Earnings Management and Firm Performance: The Case of Energy Firms in Vietnam, International Journal of Energy Economics and Policy, Econjournals, vol. 9(2), pages 307-314

Kothari, S. P., Mizik, N., \& Roychowdhury, S. (2016). Managing for the Moment: The Role of Earnings Management via Real Activities versus Accruals in SEO Valuation. The Accounting Review, 91(2), 559586. https://doi.org/10.2308/accr-51153

Lee, C.-W. J., Li, L. Y., \& Yue, H. (2005). Performance, Growth and Earnings Management. SSRN Electronic Journal. https://doi.org/10.2139/ssrn.871144

Li, Y., Niu, J., Zhang, R., \& Largay, J. A. (2011). Earnings Management and the Accrual Anomaly: Evidence from China. Journal of International Financial Management \& Accounting, 22(3), $205-245$. https://doi.org/10.1111/j.1467-646x.2011.01050.x

Linck, J. S., Netter, J., \& Shu, T. (2013). Can Managers Use Discretionary Accruals to Ease Financial Constraints? Evidence from Discretionary Accruals Prior to Investment. The Accounting Review, 88(6), 2117- 
2143. doi:10.2308/accr-50537

Linder, S., \& Foss, N. J. (2015). Agency Theory. In J. D. Wright (Ed.), International Encyclopedia of the Social \& Behavioral Sciences (2. ed., Vol. 1, pp. 344-350). Amsterdam: Elsevier. https://doi.org/10.1016/B978-008-097086-8.73038-8

Liu, Z. (2019). Unraveling the Complex Relationship between Environmental and Financial Performance: A Multilevel Longitudinal Analysis. International Journal of Production Economics. doi:10.1016/j.ijp.2019.07.005

MacKenzie, S. B., Podsakoff, P. M., \& Jarvis, C. B. (2005). The Problem of Measurement Model Misspecification in Behavioral and Organizational Research and Some Recommended Solutions. Journal of Applied Psychology, 90(4), 710-730. https://doi.org/10.1037/0021-9010.90.4.710

Matteo, P., \& Francesco, P. (2018). Earnings Management in Developing Countries. The Case of Brazilian Real Estate Industry. Academy of Accounting and Financial Studied Journal, 22(10), 1528-2635

Mikhail, M. B., Walther, B. R., \& Willis, R. H. (1999). Does forecast accuracy matter to security analysts? The Accounting Review, 74(2), 185-200

Mintz, S. (2006). Earnings Management: Causes, Techniques, and Transparent Financial Reporting. SSRN Electronic Journal. https://doi.org/10.2139/ssrn.951098

Mostafa, W. (2020). Operating performance and manipulation of accruals. Management Science Letters, 985-994. https://doi.org/10.5267/j.msl.2019.11.012

Myers, J. N., Myers, L. A., \& Skinner, D. J. (1999). Earnings Momentum and Earnings Management. SSRN Electronic Journal. https://doi.org/10.2139/ssrn.741244

Nurdiniah, D. \& Linda, H. (2015). Analysis of Factors Affecting the Motivation of Earnings Management in Manufacturing Listed in Indonesia Stock Exchange. Research Journal of Finance and Accounting, Vol.6, No.3, pp. 100-107

Nuryaman. (2013). The Influence of Earnings Management on Stock Return and the Role of Audit Quality as a Moderating Variable. International Journal of Trade, Economics and Finance, 73-78. https://doi.org/10.7763/ijtef.2013.v4.263

Okafor, T., Ezeagba, C., \& Innocent, O. (2018). Effect of Earnings Management on Performance of Corporate Organizations in Nigeria. International Journal of Business Management and Economic Review, 1(3), 25814664

Petitjean, M. (2019). Eco-friendly policies and financial performance: Was the financial crisis a game changer for large US companies? Energy Economics, 80, 502-511. https://doi.org/10.1016/j.eneco.2019.01.028

Roychowdhury, S. (2006). Earnings management through real activities manipulation, Journal of Accounting and Economics 42(3), 335-370

Ruiz, C. V, (2016). Literature review of earnings management: Who, why, when, how and what for. Finnish Business Review. http://urn.fi/urn:nbn:fi:jamk-issn-2341-9938-12

Saidu, H., Ocheni, I. O \& Muktar, J. (2017). The Impact of Earnings Management on Financial Performance of Listed Deposit Money Banks in Nigeria. Journal of Accounting and Financial Management, 3(2), 2504-8856.

Schipper, K. (1989): Commentary on earnings management. Accounting Horizons 3, pp. 91-102

Shahzad, A. (2016). Detecting Earning Management and Earning Manipulation in BRIC Countries; a Panel Data Analysis for Post Global Financial Crisis Period. International Journal of Accounting Research, 4(1). https://doi.org/10.4172/2472-114x.1000134.

Shirzad, A., Mohammadi, S., \& Haghighi, R. (2015). Effect of Financial Performance on Earnings Management in the Drug Distribution Industry. Journal of Industrial Distribution \& Business, 6(4), 23-26. https://doi.org/10.13106/ijidb.2015.vol6.no4.23.

Shuto, A. (2007). Executive compensation and earnings management: Empirical evidence from Japan. Journal of International Accounting, Auditing and Taxation, 16(1), 1-26. https://doi.org/10.1016/j.intaccaudtax.2007.01.004.

Tabassum, N., Kaleem, A., \& Nazir, M. S. (2015). Real Earnings Management and Future Performance. Global Business Review, 16(1), 21-34. https://doi.org/10.1177/0972150914553505

Tang, H.-W., \& Chang, C.-C. (2014). Does corporate governance affect the relationship between earnings management and firm performance? An endogenous switching regression model. Review of Quantitative Finance and Accounting, 45(1), 33-58. https://doi.org/10.1007/s11156-013-0427-z

Taylor, G. K., \& Xu, R. Z. (2010). Consequences of real earnings management on subsequent operating performance. Research in Accounting Regulation, 22(2), https://doi.org/10.1016/j.racreg.2010.07.008.

Tian, X., Yang, T., \& Yu, T. R. (2018). Real earnings management in family firms: evidence from Chinese listed firms. International Journal of Revenue Management, 10(2), 77. https://doi.org/10.1504/ijrm.2018.091814

Vander Bauwhede, H. \& Willeken, M. (2000). Earnings management and institutional differences Literature review and discussion. Tijdschrift voor Economie en Management, XLV (2), 189-212. 
Verma Gakhar, D. (2013). Earnings management practices in India: a study of auditor's perception. Journal of Financial Crime, 21(1), 100-110. https://doi.org/10.1108/jfc-09-2013-0054

Vorst, Patrick. (2016). Real Earnings Management and Long-Term Operating Performance: The Role of Reversals in Discretionary Investment Cuts. The Accounting Review. 91. 1219-1256. 10.2308/accr-51281.

Watts, R. L., \& Zimmerman, J. L. (1986). Positive accounting theory. Prentice-Hall Inc., 1986. Available at SSRN: http://ssrn.com/abstract $=928677$

Yiadom, B. (2016) Investigating into Earnings Management and the Performance of Selected Firms in Ghana. International Journal of Humanities and Social Studies Vol. 4, 308-321

Yorke, S. M., Amidu, M., \& Boateng, C. A. (2016). The effects of earnings management and corporate tax avoidance on firm value. International Journal of Management Practice, 9(2), 112. https://doi.org/10.1504/ijmp.2016.076741.

Ziegel, E. R., Neter, J., Kutner, M., Nachtsheim, C., \& Wasserman, W. (1997). Applied Linear Statistical Models. Technometrics, 39(3), 342. https://doi.org/10.2307/1271154. 